\title{
Front Matter: Volume 10669
}

, "Front Matter: Volume 10669," Proc. SPIE 10669, Computational Imaging III, 1066901 (25 June 2018); doi: 10.1117/12.2502366

SPIE Event: SPIE Commercial + Scientific Sensing and Imaging, 2018, Orlando, FL, United States 


\section{PROCEEDINGS OF SPIE}

\section{Computational Imaging III}

Abhijit Mahalanobis

Amit Ashok

Lei Tian

Jonathan C. Petruccelli

Editors

15-17 April 2018

Orlando, Florida, United States

Sponsored and Published by

SPIE 
The papers in this volume were part of the technical conference cited on the cover and title page. Papers were selected and subject to review by the editors and conference program committee. Some conference presentations may not be available for publication. Additional papers and presentation recordings may be available online in the SPIE Digital Library at SPIEDigitalLibrary.org.

The papers reflect the work and thoughts of the authors and are published herein as submitted. The publisher is not responsible for the validity of the information or for any outcomes resulting from reliance thereon.

Please use the following format to cite material from these proceedings:

Author(s), "Title of Paper," in Computational Imaging III, edited by Abhijit Mahalanobis, Amit Ashok, Lei Tian, Jonathan C. Petruccelli, Proceedings of SPIE Vol. 10669 (SPIE, Bellingham, WA, 2018) Sevendigit Article CID Number.

ISSN: 0277-786X

ISSN: 1996-756X (electronic)

ISBN: 9781510618497

ISBN: 9781510618503 (electronic)

Published by

SPIE

P.O. Box 10, Bellingham, Washington 98227-0010 USA

Telephone +1 3606763290 (Pacific Time) · Fax +1 3606471445

SPIE.org

Copyright (C) 2018, Society of Photo-Optical Instrumentation Engineers.

Copying of material in this book for internal or personal use, or for the internal or personal use of specific clients, beyond the fair use provisions granted by the U.S. Copyright Law is authorized by SPIE subject to payment of copying fees. The Transactional Reporting Service base fee for this volume is $\$ 18.00$ per article (or portion thereof), which should be paid directly to the Copyright Clearance Center (CCC), 222 Rosewood Drive, Danvers, MA 01923. Payment may also be made electronically through CCC Online at copyright.com. Other copying for republication, resale, advertising or promotion, or any form of systematic or multiple reproduction of any material in this book is prohibited except with permission in writing from the publisher. The CCC fee code is 0277$786 \mathrm{X} / 18 / \$ 18.00$.

Printed in the United States of America.

Publication of record for individual papers is online in the SPIE Digital Library.

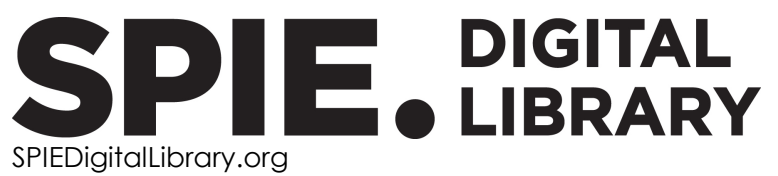

Paper Numbering: Proceedings of SPIE follow an e-First publication model. A unique citation identifier (CID) number is assigned to each article at the time of publication. Utilization of CIDs allows articles to be fully citable as soon as they are published online, and connects the same identifier to all online and print versions of the publication. SPIE uses a seven-digit CID article numbering system structured as follows:

- The first five digits correspond to the SPIE volume number.

- The last two digits indicate publication order within the volume using a Base 36 numbering system employing both numerals and letters. These two-number sets start with $00,01,02,03,04$, 05, 06, 07, 08, 09, 0A, OB ... 0Z, followed by 10-1Z, 20-2Z, etc. The CID Number appears on each page of the manuscript. 


\title{
Contents
}

\author{
$\checkmark \quad$ Authors \\ vii Conference Committee
}

\section{SESSION $1 \quad$ MACHINE LEARNING}

$1066905 \quad$ Breast cancer screening using convolutional neural network and follow-up digital mammography [10669-4]

\section{SESSION $2 \quad$ COMPUTATIONAL METHODS FOR 3D IMAGING I}

1066906 Three-dimensional integral imaging for gesture recognition under occlusions (Invited Paper) [10669-5]

$1066908 \quad$ High spatial resolution time-of-flight imaging [10669-7]

$1066909 \quad$ Evaluation of plenoptic algorithm performance for measuring scene spectra captured by a diffractive plenoptic camera [10669-8]

SESSION $3 \quad$ COMPUTATIONAL METHODS FOR 3D IMAGING II

$10669 \mathrm{OB} \quad$ Two-dimensional scattering and digital holography from isolated aerosol particles (Invited Paper) [10669-33]

\section{SESSION $4 \quad$ COMPRESSIVE SENSING}

$10669 \mathrm{OH} \quad$ An overview of joint activities on computational imaging and compressive sensing systems by NATO SET-232 (Invited Paper) [10669-15]

10669 Ol High performance image completion using sparsity based algorithms [10669-16]

10669 OJ An efficient parallel algorithm for single-pixel and FPA imaging [10669-17]

10669 OK Video compressive sensing using Russian dolls ordering of Hadamard basis for multi-scale sampling of a scene in motion using a single pixel camera [10669-18] 
10669 ON Exploiting k-space/frequency duality in Fourier optics toward real-time compression-less terahertz imaging [10669-21]

$1066900 \quad$ Feature-based sparse angle tomography reconstruction for dynamic characterization of biocellular materials [10669-22]

10669 OP Propagation-based x-ray phase imaging using focusing polycapillary optics [10669-23]

$106690 Q \quad$ Computational resolution enhancement for mesh-based x-ray phase imaging [10669-24]

SESSION $6 \quad$ NOVEL SYSTEMS AND ALGORITHMS

10669 OS Near-field SAR imaging with dynamic metasurface antennas using an adapted range migration algorithm [10669-26]

10669 OT The inversion of highly singular linear equations with applications to imaging and spectral imaging [10669-27]

10669 oU Computational imaging for reducing peak irradiance on focal planes [10669-28]

POSTER SESSION

10669 oW Machine learning for accurate differentiation of benign and malignant breast tumors presenting as non-mass enhancement [10669-31]

10669 OX Dataset adaptation for the evaluation of small object retrieval in heavily cluttered background [10669-32] 


\section{Authors}

Numbers in the index correspond to the last two digits of the seven-digit citation identifier (CID) article numbering system used in Proceedings of SPIE. The first five digits reflect the volume number. Base 36 numbering is employed for the last two digits and indicates the order of articles within the volume. Numbers start with 00, 01, 02, 03, 04, 05, 06, 07, 08, 09, 0A, 0B...0Z, followed by 10-1Z, 20-2Z, etc.

Agarwal, Sanjeev, $\mathrm{OH}$

Berg, Matthew J., OB

Boyarsky, Michael, OS

Chen, Huaijin, 08

Cossairt, Oliver, 08

Diebold, Aaron $\vee .$, OS

Dijk, Judith, $\mathrm{OH}$

Du Bosq, Todd, $\mathrm{OH}$

F. Imani, Mohammadreza, OS

Foo, Simon Y., OW

Franz, Anthony L., 09

Gorriz, Juan M., OW

Guerboukha, Hichem, ON

Güngör, Alper, $\mathrm{OH}, \mathrm{OJ}$

Güven, H. Emre, OH, OJ

Haran, Terence, $\mathrm{OH}$

Hayden, Danielle, $0 Q$

$\mathrm{He}$, Congxiao, $\mathrm{OQ}$

Heinson, Yuli W., OB

Holler, Stephen, OB

ilbey, Serhat, oJ

Illan, Ignacio Alvarez, OW

Javidi, B., 06

Kar, Oğuzhan Fatih, OJ

Kemppinen, Osku, OB

Kravets, Vladislav, OK

Kwan, Chiman, 01

Latorre-Carmona, P., 06

Laurenzis, Martin, $\mathrm{OH}$

Leonard, Kevin, $\mathrm{OH}$

Li, Fengqiang, 08

Li, Ling, 00

MacDonald, Carolyn A., OP, OQ

Mahalanobis, Abhijit, $\mathrm{OH}$

Manger, Daniel, OX

Merkulov, Alex, 05

Meyer-Baese, Anke, OW

Nallappan, Kathirvel, ON

Paunescu, Gabriela, $\mathrm{OH}$

Petruccelli, Jonathan C., OP, OQ

Pinker-Domenig, Katja, OW

Piper, Jonathan, $\mathrm{OH}$

Pla, F., 06

Pulido-Mancera, Laura, OS

Ramirez, Javier, OW

Repasi, Endre, $\mathrm{OH}$

Salvador-Balaguer, E., 06

Schau, H. C., OT

Sheng, Yunlong, $\mathrm{OH}$
Shepherd, Jack A., 09

Skorobogatiy, Maksim, ON

Sleasman, Timothy, OS

Smith, David R., OS

Stern, Adrian, OK

Sun, Weiyuan, OP

Swartzlander, Grover A., OU

Tahmassebi, Amirhessam, OW

Veeraraghavan, Ashok, 08

Watnik, Abbie T., OU

Wirth, Jacob H., OU

Wu, Ziling, 00

Yang, Clifford, 05

Yang, Ting, 00

Yeh, Chia-Kai, 08

Zheng, Yufeng, 05

Zhou, Jin, Ol

Zhu, Yunhui, 00 
Proc. of SPIE Vol. 10669 1066901-6

Downloaded From: https://www.spiedigitallibrary.org/conference-proceedings-of-spie on 26 Apr 2023 Terms of Use: https://www.spiedigitallibrary.org/terms-of-use 


\section{Conference Committee}

Symposium Chair

Robert D. Fiete, Harris Corporation (United States)

Symposium Co-chair

Jay Kumler, JENOPTIK Optical Systems, LLC (United States)

Conference Chairs

Abhijit Mahalanobis, Lockheed Martin Missiles and Fire Control (United States)

Amit Ashok, College of Optical Sciences, The University of Arizona (United States)

Lei Tian, Boston University (United States)

Jonathan C. Petruccelli, University at Albany (United States)

Conference Program Committee

Oliver Cossairt, Northwestern University (United States)

Michael E. Gehm, Duke University (United States)

Ulugbek Kamilov, Mitsubishi Electric Research Laboratories (United States)

Jun Ke, Beijing Institute of Technology (China)

Chrysanthe Preza, The University of Memphis (United States)

Adrian Stern, Ben-Gurion University of the Negev (Israel)

Andreas Velten, University of Wisconsin-Madison (United States)

Laura Waller, University of California, Berkeley (United States)

Ge Wang, Rensselaer Polytechnic Institute (United States)

Abbie Watnik, U.S. Naval Research Laboratory (United States)

Zeev Zalevsky, Bar-llan University (Israel)

Yunhui Zhu, Virginia Polyłechnic Institute and State University (United States)

Session Chairs

1 Machine Learning

Jonathan C. Petruccelli, University at Albany (United States)

2 Computational Methods for 3D Imaging I

Lei Tian, Boston University (United States) 
3 Computational Methods for 3D Imaging II

Abhijit Mahalanobis, Lockheed Martin Missiles and Fire Control (United States)

4 Compressive Sensing

Amit Ashok, College of Optical Sciences, The University of Arizona (United States)

5 Computational Imaging Outside the Visible Regime

Lei Tian, Boston University (United States)

6 Novel Systems and Algorithms

Jonathan C. Petruccelli, University at Albany (United States) 